\title{
Relationship between soil nurient concentration and plant nutrient status
}

\author{
Viljo PuUstjärvi \\ Peat Research Institute
}

\begin{abstract}
Foliar diagnosis as a method for assessing the nutrient status in a grownig medium seems to be useful. It gives the relationship between the available soil nutrient concentration and the plant nutritional status. The proportionality factor (k), a parameter in the given logarithmic equation, is called the efficiency coefficient. It indicates the ability of a plant to absorb nutrients from its growing medium.
\end{abstract}

From the feeding point of view the grower needs reliable advice on a number of important questions.

1. How to assess the current nutritional status of the crop.

2. What is the nutritional level in plant and soil required at specific stages of growth?

3. What quantities of nutrients are required to keep the soil nutrient concentration at optimum level?

4. What is the relationship between available soil nutrient concentration and the plant nutritional status?

If answers could be provided to all of these questions, the maximum crop potential for any given environment could be attained. By means of a basis peat culture technique, developed in the Peat Research Institute (2), it is possible operationally to meet plant nutrient requirements. In addition to this technique the recommendations for nutrient levels in growing medium - based on greenhouse experiments - are given. What is needed is the optimum plant nutritional level and the relationship between available soil nutrient levels and plant nutrient contents.

It is well known that plants grown in culture solutions rarely absorb the various ions in the proportions in which they are supplied. Plants exert a selective action and this selectivity varies with the type of plant. Consequently it cannot be expected that plants grown in soil will abdsorb ions in the proportion in which the ions occur in the soil solution, in an exchangeable form, or in any other form. The proportionate quantities of the nutrients absorbed by plants can be predicted, nevertheless, on the basis of coefficients that are determined empirically. 
The activities of the water soluble and the exchangeable bases are not equal. The proportions of the water soluble and the exchangeable bases are not the same in soils. The proportionate quantities of the bases absorbed by plants from various soils, therefore, cannot be equal, and so the coefficients that are determined empirically are valid only for the soil used in ecxperiments.

In the present study light Sphagnum moss peat has been used as the growing medium. The purpose of the work is to demonstrate the relationship between available nutrient concentration in peat and the plant nutritional status. $\mathrm{NO}_{-}$ $\mathrm{N}$ has been used as the test nutrient.

\section{Material and methods}

Growing medium:
Light Sphagnum moss peat
Volume weight: $60 \mathrm{~g} / 1$
Pore volume: $96 \%$
Average water space during culture: about $45 \%$
Available nitrogen: about $15-30 \mathrm{mg} / \mathrm{l}$ in the form of $\mathrm{NH}_{4}$, the rest (mainly) in the from of $\mathrm{NO}_{3}$. Only $\mathrm{NO}_{3}-\mathrm{N}$ was analyzed.
Available potassium: about $70-80 \%$ in soil solution, the rest in exchangeable form. Potassium figures in the following refer to the sum of water- soluble and exchangeable potassium.
Method of analysis: Described in a previous paper (PUUSTJÄRvi 1971).

Test plant:

Test plant: Carnation, growth cycle 2 years.

Sampling:

Sampling: Peat samples from the four to eight replicate plots were taken twice a month, leaf samples once a month.

\section{Introduction}

Foliar diagnosis as a method for assessing the fertilizer requirements of a given crop is based on the assumption that within certain limits there is a positive correlation among doses of nutrient supplied, the leaf content of this element, and the yield. This method of studying problems of soil fertility involves the use of the plant itself as an extracting agent for its nutrients.

It is shown that the response of plants to nutrients is described by the function

$$
\begin{gathered}
Y=f(X) \\
\text { or even better by the function } \\
Y=f(X, P t)
\end{gathered}
$$

where $\mathrm{Y}=$ yield or level of element in the leaves corresponding to $\mathrm{X}=$ dosage of element. Pt is a function describing the plant during its growth period. 
In the study the response of plants to nutrients is considered as the response to an average amount of nutrient available to the test plant during its whole growth cycle (2 years). This does not mean that the nutrient contents of the leaves would have been at the same level during the whole cycle. On the contrary, the nitrogen and potassium contents have varied with the seasons. In winter, when the growth rate has been slow, the nitrogen and potassium contents have been high. In summer time, when the growth rate has been fast, the contents have been low (Fig. 1) The changes in the contents of other nutrients in the leaves during the growth cycle have been almost insigniticant.

Extensive experimental work in predicting the proportionate content of nutrients in plants from measurements on growing mediums has been done by many investigators.

Fore xample, it was established with reasonable probability by HewitT (1957) that the total uptake of a nutrient (in a study of copper, manganese, phosphorus, molybdenum and strontium) into whole plants, and often parts of plants, is related to the nutrient supply in a manner which approximates the following equation:

$$
\lg \mathrm{N}=\mathrm{k} \lg \mathrm{S} \text {, }
$$

were $\mathrm{N}$ is the total content of the element in plants, leaves or stem, and $\mathrm{S}$ is the concentration of nutrient solution (water culture). It was also shown that the yield of dry material (Y) of plants grown in these experiments was linearly related to the logarithm of the concentration of the nutrient element in solution when given as a series of concentrations ranging from deficiency to optimal conditions:

where $\mathrm{Y}=$ yield and

$$
\lg \mathrm{N}=\lg \mathrm{Y}+\lg \mathrm{C} \text {, }
$$

$\mathrm{C}=$ concentration of the element in the respective part or whole plant. In the present study the above-mentioned equation (3) presented by HewitT has been used as a basic equation.

\section{Efficiency Coefficient}

The rate of uptake of a single nutrient by a plant can be assumed to be dependent

1. on the nutrient activity in the growing medium, and

2. on the efficiency of the plant in absorbing nutrients.

The efficiency of the plant in absorbieng nutrients depends on many factors. Some of them are connected with the growing medium (free energy of the water, osmotic value of the soil solution, ventilation, nutrient status, etc.) some with the greenhouse climate (night and day temperatures, relative humidity, etc.) and some with the plant itself.

In the present study the value of $\mathrm{k}$ in the equation (3) is suppo sed to indicate the efficiency of the plant in absorbing nutrients. It is therefore called the efficiency coefficient. Its value is only relative because it does not indicate directly the efficiency of the plant's light energy utilization. 
Table 1. The effect of increasing applications of nitrogen on the efficiency coefficient of nitraet (k). (Experiments $1-3$ in glasshouses, experiment in plastic house).

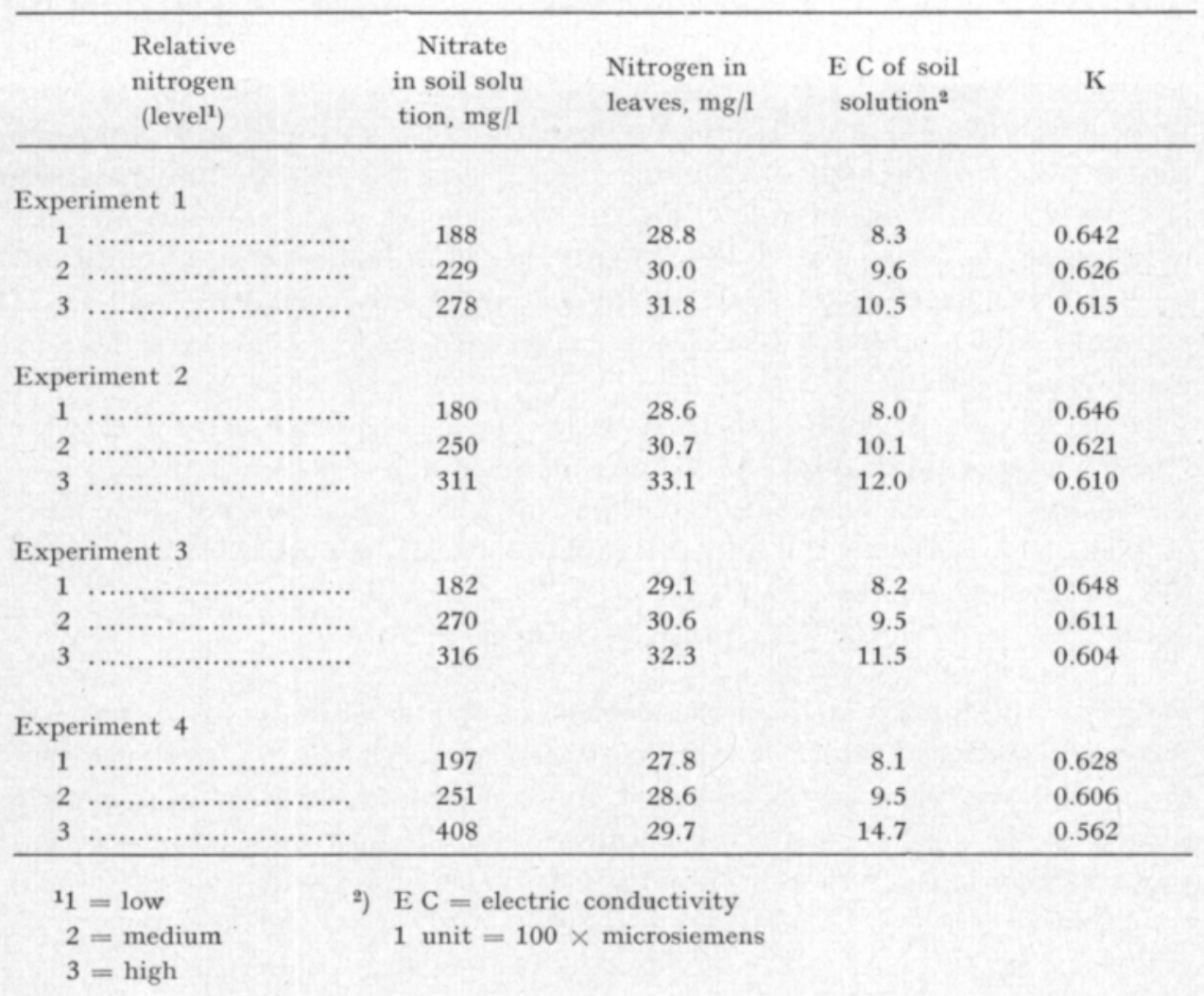

Increasing the salinity of the soil solution and its effect on the efficiency of the plant's nitrogen uptake

Table 1 and Fig. 1 show the effect of incresed nitrogen concentration on the efficiency of the nitrogen uptake by a plant. It appears that the efficiency $(k)$ decreases when the concentration $(\mathrm{mg} / \mathrm{l})$ increases. This is probably due to a decrease in the nitrate activity. An attempt was made to calculate the activity coefficient for the nitrate.

The activity of the water soluble nutrients can be calculated from familiar equations such as

$$
-\log f_{i}=\frac{0.5 \mathrm{Zi}^{2} \sqrt{\mathrm{I}}}{1+\sqrt{\mathrm{I}}}
$$

were $f_{i}=$ the activity coefficient of the ions, $\mathrm{Zi}$ their valence and $\mathrm{I}=$ the ionic strength of the solution.

The ionic strengths (I) of the soil solutions in the presented experiments can be salculated roughly by the aid of the electric conductivity (EC) of the 


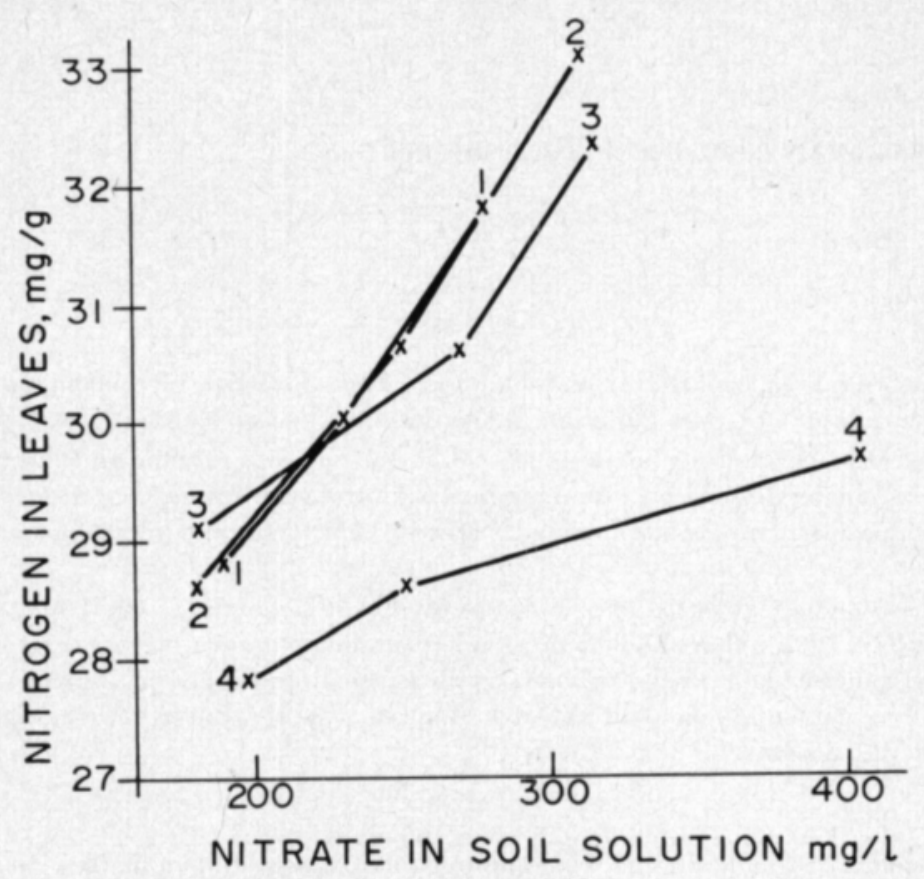

Fig. 1. Eeffect of nitrate concentration of soil solution on leaf N.

soil solutions (given in Table 1.). The average water space of the growing medium can be esimated at about $\mathbf{5 0} \%$.

$$
\mathrm{I}=0.05 \mathrm{EC}
$$

The results were not satisfying. This may be due to the following factors:

1. The equation (5) is supposed to be useful if the value of I does not exceed 0.1 . In the present material its average value has been about 0.5 .

2. During the culture the water space has not been constant. The value of I has varied with the water space.

3. $\mathrm{NH}_{4}-\mathrm{N}$, which has not been taken into consideration, may have had a significant effect on the nitrogen uptake.

\section{REFERENCES}

Hewitr, E. J. 1957. Plant analysis and fertilizer problems. Proc. 6th Int. Congr. Soil Sci. 1956.

Pưstjärvi, V. 1969. Basino - Peat culture. Peat \& Plant News 2, 1969.

- 1971. Methods of analyzing peat in peat culture. Peat \& Plant Yearbook 1971. Helsinki. 


\section{SElostus}

\section{Maa- ja kasvianalyysien keskinäiset suhteet}

\section{Viljo PuUstjärvi \\ Turvetutkimuslaitos}

Lannoitustarpeen ilmentäjänä on kasvihuoneviljelyssä totuttu käyttämäăn maa-analyysiä. Maa-analyysin tulkinta tuottaa kuitenkin melkoisia vaikeuksia. Tulkintavaikeuksien on katsottu ensisijaisesti aiheutuneen kahdesta eri tekijästä: toisaalta ravinneionien aktiivisuuksien vaihteluista eri alustoissa sekä eri kosteustileissa sekä toisaalta siitä, että kasvien ravinteidenottokyky vaihtelee kasvin kunnon mukaan. Kasvin kunto määräytyy kaikkien kasvutekijäin yhteistuloksena.

Kullakin kasvilla on katsottu olevan optimiravinnepitoisuutensa. Jos nämă voidaan olettaa tunnetuiksi - kuten yleensä tehdään - saataisiin helppotöinen maa-analyysi entista mielekkäämmäksi tuntemalla maa- ja kasvianalyysin keskinäiset riippuvuussuhteet.

Vuosikausia kestäneiden laajojen tutkimusten tuloksena on alla esitetty yhtälö osoittautunut erittäin käyttökelpoiseksi.

$$
\lg \mathbf{N}=\mathbf{k} \lg \mathrm{S} \text {, }
$$

missä $\mathrm{N}$ on kasvin ravinnepitoisuus (esim. promilleina) ja $\mathrm{S}$ ravinteen maassa oleva väkevyys (esim. mg/1.) Kerrointa k on nimitetty tehokertoimeksi, koska se ilmentää kasvin ravinteidenottokykyä. Sen arvo vaihtelee ravinteen mukaan.

Kertoimen k arvo määräytyy myös alustassa olevien ravinteiden aktiivisuuksien mukaan. Jos muut kasvutekijät ovat samat, ilmentävät k:n vaihtelut tutkittavan ravinteen aktiivisuuksien vaihteluja. Tutkimuksessa on kiinnitetty aivan erityistä huomiota siihen, kuinka johtoluku vaikuttaa k:n arvoon. Laskelmissa on käytetty hyväksi kaavaa

$$
-\lg \mathrm{fi}=\frac{0.5 \cdot \mathrm{Zi}^{2} \sqrt{\mathrm{I}}}{1+\sqrt{\mathrm{I}}}
$$

missä I on ionivahvuus. Se on laskettu kaavasta

$$
\mathrm{I}=0.05 \mathrm{EC} \text {, missä } \mathrm{EC} \text { on johtoluku. }
$$

Saadut tulokset eivät olleet tyydyttäviä, mutta kuitenkin lupaavia. 